COMMERCIAL-SCALE DEMONSTRATION OF THE LIQUID PHASE METHANOL (LPMEOH ${ }^{T M}$ ) PROCESS

\title{
TECHNICAL PROGRESS REPORT NO. 1
}

\author{
For The Period
}

October 1, 1993 to June 30, 1994
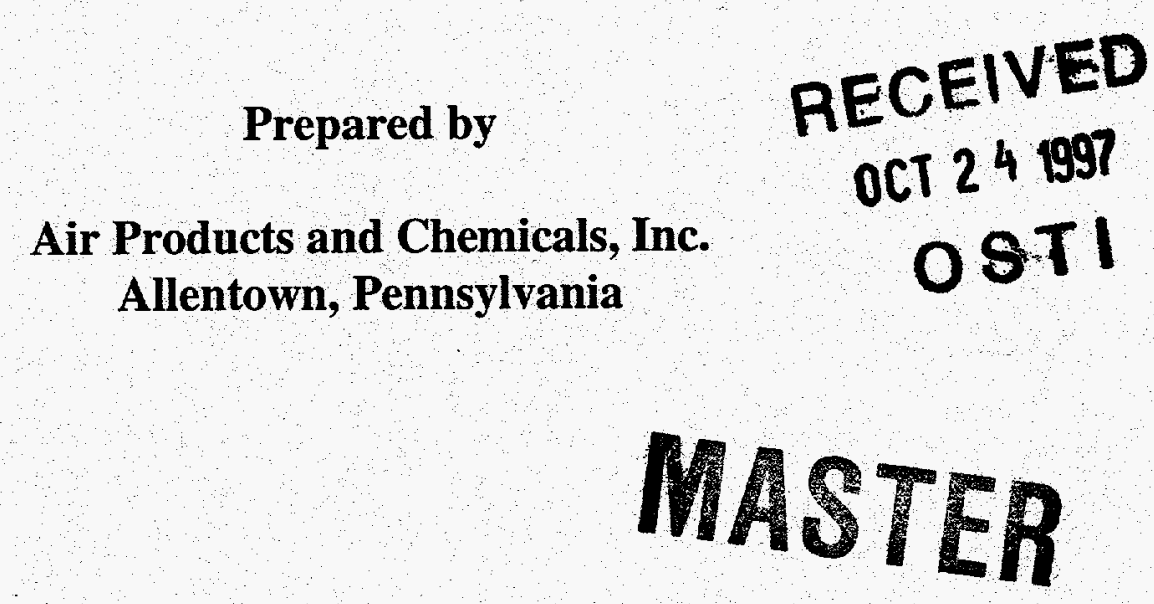

DISTRDUTON OF THIS DOCUMENT is

\begin{abstract}
Prepared for the United States Department of Energy
Pittsburgh Energy Technology Center

Under Cooperative Agreement No. DE-FC22-92PC90543

Patents cleared by Chicago on 5/30/97
\end{abstract}




\section{DISCLAIMER}

This report was prepared as an account of work sponsored by an agency of the United States Government. Neither the United States Government nor any agency thereof, nor any of their employees, makes any warranty, express or implied, or assumes any legal liability or responsibility for the accuracy, completeness, or usefulness of any information, apparatus, produet, or process disclosed, or represents that its use would not infringe privately owned rights. Reference herein to any specific commercial product, process, or service by trade name, trademark, manufacturer, or otherwise does not necessarily constitute or imply its endorsement, recommendation, or favoring by the United States Government or any agency thereof. The views and opinions of authors expressed herein do not necessarily state or reflect those of the United States Government or any agency thereof. 


\section{DISCLAIMER}

Portions of this document may be illegible electronic image products. Images are produced from the best available original document. 


\section{DISCLAIMER}

This report was prepared by Air Products \& Chemicals, Inc., pursuant to a Cooperative Agreement partially funded by the U.S. Department of Energy, and neither Air Products \& Chemicals, Inc., nor any of their subcontractors nor the U.S. Department of Energy, nor any person acting on behalf of either:

(A) Makes any warranty or representation, express or implied, with respect to the accuracy, completeness, or usefulness of the information contained in this report, or that the use of any information, apparatus, method, or process disclosed in this report may not infringe privately owned rights; or

(B) Assumes any liabilities with respect to the use of, or for damages resulting from the use of, any information, apparatus, method, or process disclosed in this report.

Reference herein to any specific commercial product, process, or service by trade name, trademark, manufacturer, or otherwise, does not necessarily constitute its endorsement, recommendation, or favoring by the U.S. Department of Energy. The views and opinions of authors expressed herein does not necessarily state or reflect those of the U.S. Department of Energy. 


\section{ACRONYMS AND DEFINITIONS}

\begin{tabular}{|c|c|}
\hline Acurex & - Acurex Environmental Corporation \\
\hline Air Products & - Air Products and Chemicals, Inc. \\
\hline AFDU & - Alternative Fuels Development Unit - The "LaPorte PDU." \\
\hline Balanced Gas & $\begin{array}{l}\text { A syngas with a composition of hydrogen }\left(\mathrm{H}_{2}\right) \text {, carbon monoxide }(\mathrm{CO}) \text {, and carbon dioxide } \\
\left(\mathrm{CO}_{2}\right) \text { in stoichiometric balance for the production of methanol }\end{array}$ \\
\hline Carbon Monoxide Gas & A syngas containing primarily carbon monoxide $(\mathrm{CO})$; also called $\mathrm{CO}$ Gas \\
\hline DME & - dimethyl ether \\
\hline DOE & - United States Department of Energy \\
\hline DOE-PETC & - The DOE's Pittsburgh Energy Technology Center (Project Team) \\
\hline DOE-HQ & The DOE's Headquarters - Clean Coal Technology (Project Team) \\
\hline DTP & - Demonstration Test Plan - The four year Operating Plan for Phase 3, Task 2 Operation \\
\hline DVT & - Design Verification Testing \\
\hline Eastman & - Eastman Chemical Company \\
\hline EIV & - Environmental Information Volume \\
\hline EMP & - Environmental Monitoring Plan \\
\hline EPRI & - Electric Power Research Institute \\
\hline HAPs & - $\quad$ Hazardous Air Pollutants \\
\hline Hydrogen Gas & $\begin{array}{l}\text { A syngas containing an excess of hydrogen }\left(\mathrm{H}_{2}\right) \text { over the stoichiometric balance for the } \\
\text { production of methanol; also called } \mathrm{H}_{2} \text { Gas }\end{array}$ \\
\hline IGCC & - Integrated Gasification Combined Cycle, a type of electric power generation plant \\
\hline IGCC/OTM & - An IGCC plant with a "Once-Thru Methanol" plant (the LPMEOH ${ }^{\mathrm{M}}$ Process) added-on. \\
\hline KSCFH & - Thousand Standard Cubic Feet per Hour \\
\hline LaPorte PDU & $\begin{array}{l}\text { - The DOE-owned experimental unit (PDU) located adjacent to Air Product's industrial gas } \\
\text { facility at LaPorte, Texas, where the LPMEOH }{ }^{\top M} \text { process was successfully piloted. }\end{array}$ \\
\hline LPDME & $\begin{array}{l}\text { - Liquid Phase DME process, for the production of DME as a mixed coproduct with } \\
\text { methanol }\end{array}$ \\
\hline LPMEOH $^{\mathrm{M}}$ & - Liquid Phase Methanol (the technology to be demonstrated) \\
\hline MTBE & - methyl tertiary butyl ether \\
\hline NEPA & - National Environmental Policy Act \\
\hline OSHA & Occupational Safety and Health Administration \\
\hline Partnership & Air Products Liquid Phase Conversion Company, L.P. \\
\hline PDU & Process Development Unit \\
\hline PFD & Process Flow Diagram(s) \\
\hline ppb & parts per billion \\
\hline Project & $\begin{array}{l}\text { Production of Methanol/DME Using the LPMEOH }{ }^{\top M} \text { Process at an Integrated Coal } \\
\text { Gasification Facility }\end{array}$ \\
\hline psia & - Pounds per Square Inch (Absolute) \\
\hline psig & - $\quad$ Pounds per Square Inch (gauge) \\
\hline P\&ID & Piping and Instrumentation Diagram(s) \\
\hline SCFH & Standard Cubic Feet per Hour \\
\hline SI/hr-kg & Standard Liter(s) per Hour per Kilogram of Catalyst \\
\hline Syngas & - Abbreviation for Synthesis Gas \\
\hline Synthesis Gas & $\begin{array}{l}\text { A gas containing primarily hydrogen }\left(\mathrm{H}_{2}\right) \text { and carbon monoxide }(\mathrm{CO}) \text {, or mixtures of } \mathrm{H}_{2} \\
\text { and } \mathrm{CO} \text {; intended for "synthesis" in a reactor to form methanol and/or other hydrocarbons } \\
\text { (synthesis gas may also contain } \mathrm{CO}_{2} \text {, water, and other gases) }\end{array}$ \\
\hline Tie-in(s) & $\begin{array}{l}\text { - the interconnection(s) between the LPMEOH }{ }^{\top M} \text { Process Demonstration Facility and the } \\
\text { Eastman Facility }\end{array}$ \\
\hline TPD & - $\quad$ Ton(s) per Day \\
\hline $\begin{array}{l}\text { WBS } \\
\text { wt }\end{array}$ & $\begin{array}{l}\text { - Work Breakdown Structure } \\
\text { - weight }\end{array}$ \\
\hline
\end{tabular}




\section{Executive Summary}

The Liquid Phase Methanol (LPMEOH ${ }^{\top M}$ ) Demonstration Project at Kingsport, Tennessee is a $\$ 213.7$ million cooperative agreement between the U.S. Department of Energy (DOE) and Air Products and Chemicals, Inc. (Air Products). The demonstration is sited at the Eastman Chemical Company (Eastman) complex in Kingsport. Air Products and Eastman are working on a partnership agreement which will form the Air Products Liquid Phase Conversion Company, L.P. As a limited partner in the venture, Eastman will own and operate the demonstration unit.

The project involves the construction of a 260 tons-per-day (TPD) or 80,000 gallon per day methanol demonstration unit utilizing an existing coal-derived synthesis gas from Eastman. The new equipment consists of synthesis gas feed preparation and compression, liquid phase reactor and auxiliaries, product distillation, and utilities.

The technology to be demonstrated was developed by Air Products in a DOE sponsored program that started in 1981. Originally tested at a small, DOE-owned experimental facility in LaPorte, Texas, the $\mathrm{LPMEOH}^{\mathrm{TM}}$ process offers several advantages over current methods of making methanol. This liquid phase process suspends fine catalyst particles in an inert liquid, forming a slurry. The liquid dissipates heat from the chemical reaction away from the catalyst surface, protecting the catalyst, and allowing the gas-to-methanol reaction to proceed at higher rates. The process is ideally suited to the type of gas produced by modern coal gasifiers. At the Eastman Chemical complex, the technology will be integrated with existing coal gasifiers to demonstrate the commercially important aspects of the operation of the LPMEOH ${ }^{\mathrm{TM}}$ Process to produce methanol.

A four-year demonstration will prove the commercial applicability of the process. An off-site productuse test program will prove the suitability of the methanol as a transportation fuel and as a fuel for stationary applications in the power industry. In future commercial facilities, advanced coal-tomethanol processes may be a cost-enhancing option for coal gasification-based power plants. Future 
facilities úsing "integrated gasification-combined-cycle technology" will produce methanol as a coproduct during times of low electricity demand, allowing the gasifiers to operate at steady, peak performance.

This project may also demonstrate the production of dimethyl ether (DME) as a mixed coproduct with methanol if laboratory- and pilot-scale research and market verification studies show promising results. If implemented, the DME would be produced during the last six months of the four-year demonstration period. DME has several commercial uses. In a storable blend with methanol, the mixture can be used as a peaking fuel in gasification-based electric power generating facilities. Blends of methanol and DME can be used as chemical feedstocks for synthesizing chemicals, including new oxygenated fuel additives.

The project was reinitiated in October of 1993, when DOE approved a site change to the Kingsport location. Since that time, project definition activities have been on-going. The project requires review under the National Environmental Policy Act (NEPA) to move to the construction phase, which is scheduled to begin in August of 1995. Air Products and Eastman are working on an Environmental Information Volume (EIV) which will be used by the DOE to prepare an Environmental Assessment (EA) and Finding of No Significant Impact (FONSI), which are necessary to complete this review process. The facility is scheduled to be mechanically complete in November of 1996.

\section{A. Introduction}

The Liquid Phase Methanol (LPMEOH ${ }^{\top \mathrm{M}}$ ) demonstration project at Kingsport, Tennessee, is a \$213.7 million cooperative agreement between the U.S. Department of Energy (DOE) and Air Products and Chemicals, Inc. (Air Products). A facility producing 80,000 gallons per day of methanol will be located at the Eastman Chemical (Eastman) facility in Kingsport, Tennessee. Under a proposed partnership agreement, Eastman will be a limited partner in the venture, which will own and operate the demonstration unit for the four-year operating period. This project is sponsored under the DOE's Clean Coal Technology Program and its objective is to 
"demonstrate, at a commercial scale, the production of methanol from coal-derived synthesis gas using the $\mathrm{LPMEOH}^{\mathrm{TM}}$ process. The project will also determine the suitability of the methanol produced for use as a chemical feedstock or as a low-sulfur dioxide, low-nitrogen oxides alternative fuel in stationary and transportation applications."

The Kingsport project may also demonstrate the production of dimethyl ether (DME) as a mixed coproduct with methanol if laboratory- and pilot-scale research shows promising results. If implemented, the DME would be produced during the last six months of the four-year demonstration period.

The LPMEOH ${ }^{\mathrm{TM}}$ process was developed by Air Products in a DOE-sponsored program that started in 1981 . It was successfully piloted at a 10 TPD $(3,200$ gallons per day) rate in the DOE-owned facility at Air Products' LaPorte, Texas site. This demonstration project is the culmination of this extensive effort.

\section{B. Project Description}

\section{Existing Site}

The site for this demonstration is the Eastman complex located in Kingsport, Tennessee. This major chemical complex is spread over almost 4,000 acres and employs approximately 12,000 people. In 1983 Eastman constructed a coal gasification facility utilizing Texaco technology. The synthesis gas generated by this gasification facility is used to produce carbon monoxide and methanol. Both of these products are used to produce methyl acetate and ultimately cellulose acetate and acetic acid. The availability of this highly reliable coal gasification facility was the major factor in selecting this location for the $\mathrm{LPMEOH}^{\mathrm{TM}}$ Process Demonstration. The existing methanol unit (gas phase Lurgi technology) will be operated at turndown since some of the feed gas will be diverted to the LPMEOH ${ }^{\mathrm{TM}}$ demonstration unit. 
The proposed project includes these four major process areas with their associated equipment:

- Reaction Area

- Purification Area

- Catalyst Preparation Area

- Storage/Utility Area

The physical appearance of this facility will closely resemble the adjacent Eastman process units, including process equipment in steel structures.

\section{Reaction Area}

The reaction area will include feed gas compression and catalyst guard beds, the reactor, a steam drum, separators, heat exchangers, and pumps. The equipment will be supported by a matrix of structural steel. The most salient feature will be the reactor, since with supports, it will be approximately 84 -feet tall.

\section{Purification Area}

The purification area will feature two distillation columns with supports; one will be approximately 82 -feet tall, and the other 97 -feet tall. These vessels will resemble the columns of the surrounding process areas. In addition to the columns, this area will include the associated reboilers, condensers, air coolers, separators, and pumps.

\section{Storage/Utility Area}

The storage/utility area will include two diked lot-tanks for methanol, two tanks for oil storage, a slurry holdup tank, trailer loading/unloading area, and a buried oil/water separator. 


\section{Catalyst Preparation Area}

The catalyst preparation area will be housed in a building with a roof and partial walls, in which the catalyst preparation vessels, slurry handling equipment, and spent slurry disposal equipment will be located. In addition, a hot oil utility system is included in the area.

\section{Process Description}

The LPMEOH ${ }^{\mathrm{TM}}$ demonstration unit will be integrated with Eastman's coal gasification process train and operated in parallel with an existing Lurgi technology methanol unit. A simplified process flow diagram is included in Appendix A. When the LPMEOH ${ }^{\mathrm{M}}$ demonstration unit is operating, the Lurgi unit will be turned down. Synthesis gas will be introduced into the slurry reactor, which contains liquid mineral oil with suspended solid particles of catalyst. The synthesis gas dissolves through the oil, contacts the catalyst, and reacts to form methanol. The heat of reaction is absorbed by the mineral oil and is removed from the oil by steam coils. The methanol vapor leaves the reactor and is condensed to a liquid, sent to the distillation columns for removal of higher alcohols, water, and other impurities, and is then stored in the day tanks for sampling before being sent to Eastman's methanol storage. Most of the unreacted synthesis gas is recycled back to the reactor with the synthesis gas recycle compressor, improving cycle efficiency. The methanol will be used for downstream feedstocks and in off-site fuel testing to determine its suitability as a transportation fuel and as a fuel for stationary applications in the power industry.

\section{Project Status}

During the period October 1, 1993 to June 30,1994, the project definition activities have been on-going. Major accomplishments during this period are as follows: 


\section{Project Management Plan}

\section{$\underline{\text { Reviews }}$}

- A Preliminary Hazards Review (PHR) is required by Air Products safety procedures. This review was conducted in January of 1994. The PHR report is attached as Appendix B.

\section{Agreements}

- Final partnership agreements between Air Products and Eastman are nearly in place. These agreements are a necessary part of the Continuation Application.

- The Continuation Application to move the project into the design phase is expected to be submitted in August of 1994.

\section{Technology Baseline}

\section{Process Design}

- Demonstration Unit Design basis was established.

- A demonstration plan detailing specific operating cases to cover the 208-week demonstration period was prepared for preliminary review.

- The Process Flow Diagram (PFD) was prepared to the Rev. 0 status. Efforts to develop the detailed Piping and Instrument Diagram (P\&ID) were initiated.

- Process Equipment specifications are approximately $10 \%$ complete.

\section{Design Engineering}

- The compressor mechanical specification was developed and released for bid. Bids are currently being reviewed. The purchase order is expected to be placed in August of 1994.

- The reactor mechanical specification is nearly complete and will be the subject of a review meeting in early August of 1994. The compressor and reactor are the items that have most impact on the schedule. 
- Discussions have taken place between Eastman's and Air Products' Machinery and Operation personnel. These discussions will produce an agreement on the basic design criteria for the machinery items.

- A preliminary plot plan was issued and included in the June 1994 Draft Environmental Information Volume (EIV) submitted to DOE.

\section{Schedule Baseline}

- The milestone schedule, (see Appendix C), has the following key dates:

- Complete NEPA Review

- Begin Construction Period

- Complete Field Construction

- Begin Operation

- Complete Operation
May 15, 1995

July 15,1994

October 30, 1996

October 16, 1996

November 3, 2000

\section{Cost Baseline}

A Cost Plan is being developed and will be submitted with the Continuation Application. A current Cost Management report is included in Appendix D.

\section{Financial Commitment}

Air Products and Eastman are working on a Partnership Agreement that will secure the demonstration site and provide for the financial commitment and management of the Project.

\section{National Environmental Policy Act}

- Two versions (the latest in June of 1994) of the Environmental Information Volume (EIV) have been submitted to the DOE for review and use in preparing the Project's Environmental Assessment (EA). Outstanding issues on the EIV are the off-site product-use test program and the DME provisional add-on demonstration. Both of 
these issues are being addressed; the off-site testing by Acurex and the DME by Air Products.

\section{E. Planned Activities}

For the next reporting period the project is expected to progress into detailed design. Air

Products plans to submit the project's Continuation Application requesting DOE approval to begin detailed design and construction. Work will continue on the process equipment specification, and the distillation columns and major heat exchanger specifications should be released for mechanical design. A purchase order should be placed for the compressor, and the reactor should be released for bidding.

The P\&ID should be nearing a first preliminary issue (Rev. P). A revised EIV document should be submitted. A design engineering schedule should be released.

\section{F. Summary}

Project definition activities are proceeding with haste. Partnership arrangements between Air Products and Eastman are being developed. Specifications for the long-lead time process equipment are being prepared.

The project is proceeding as planned with no major road blocks anticipated. 
APPENDIX A SIMPLIFIED PROCESS DIAGRAM 1 Page 
SIMPLIFIED PROCESS DIAGRAM

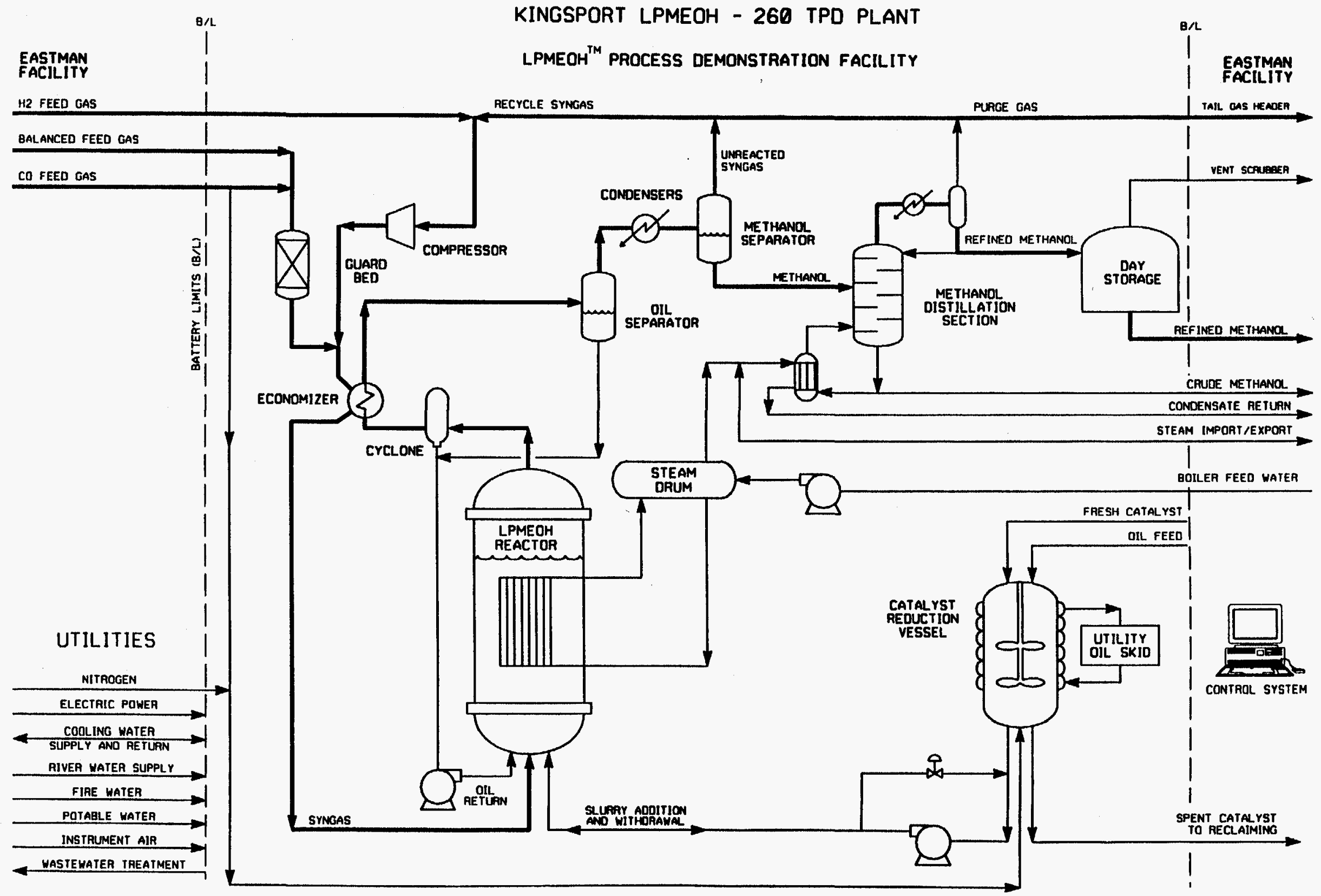


APPENDIX B PRELIMINARY HAZARDS REVIEW 26 Pages 


\section{PRELIMINARY HAZARDS REVIEW}

KINGSPORT LIQUID PHASE METHANOL PROJECT

PROJECT NO. 00-3-8215

KINGSPORT, TENNESSEE

TO BE DESIGNED AND BUILT BY AIR PRODUCTS AND CHEMICALS, INC.

AND OPERATED BY EASTMAN CHEMICAL COMPANY

REVIEW DATES: 27 AND 28 JANUARY 1994

ISSUE DATE: 31 MAY 1994

Review Team
APCI:
D. Bernhard
E. Heydorn
D. Bixler
W. Brown
T. Conway*
A. Fleischer*
R. Moore*
E. Schaub
V. Stein
* Part-Time
Eastman Chemical Company:
L. Daniels
W. Jones
M. Templeton 


\section{PRELIMINARY PROCESS HAZARDS REVIEW \\ KINGSPORT LIQUID PHASE METHANOL PROJECT \\ KINGSPORT, TENNESSEE}

\section{TABLE OF CONTENTS}

\section{Pages}

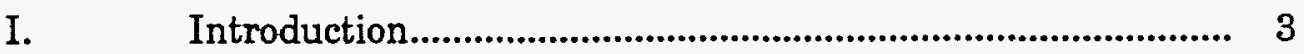

II. Scope of Review .................................................................. 3

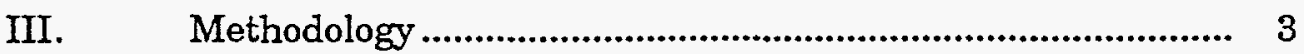

IV. Preliminary Hazards Review Team .................................. 3

V. Process Description .................................................... 4

VI. Notes from Preliminary Hazards Review........................... 4

VII. Identification of Potential Major Hazards (Worksheets) ....... 7

\section{Appendices}

1. Agenda for 1/27/94 Preliminary Hazards Review

2. LPMEOH Project Safety Plan, 1/17/94

3. Process Flow Diagrams, Rev. 0, Sheets 1-5 


\section{INTRODUCTION}

A Preliminary Hazards Review (PrHR) was conducted on 27 and 28 January 1994 for the Kingsport LPMEOH project. This project will install a nominal 260 tons per day slurry phase methanol synthesis plant in Eastman Chemical's Kingsport, Tennessee facility.

The purpose of the PrHR is to identify major potential hazards associated with the process and plant to ensure these items will be considered during the design phase of the project.

\section{SCOPE OF REVIEW}

The scope of the review includes all operating sections of the LPMEOH plant. We did not review the impact of tie-ins to existing Kingsport systems connected to the LPMEOH plant. We also did not discuss any fuel demonstration scope of work. This work will be done by Eastman on-site and by Aurex offsite.

\section{METHODOLOGY}

The preliminary hazards review is the first safety review in a series of project reviews for the LPMEOH project. The project is in project definition phase. Preliminary PFD's were available to use as a basis for the review (Appendix 3). The review followed APCI's standard practice 1009B for Project Safety Reviews. A copy of the agenda is attached as Appendix 1. Hazards were identified and recommendations were made for consideration during the design phase of the project.

IV. PRELIMINARY HAZARDS REVIEW TEAM MEMBERS

The PrHR review team consisted of the following personnel:

$\underline{\mathrm{APCI}}$

D. Bernhard

A. D. Bixler

W. Brown

D. Drown

A. Fleischer

E. Heydorn

R. Moore

E. Schaub

V. Stein
PSG Engineering Safety

PSG Engineering Technology

Equipment \& Business Development

PSG Project Engineering

PSG Machinery Engineering

PSG LaPorte Production \& Delivery

PSG Project Development

PSG Process Engineering

PSG Process Engineering

\section{Eastman Chemical Company}

L. Daniels

W. Jones

M. Templeton
Chemicals Customer Focus Team

Chemicals From Coal Expansion Project

Plant Protection Technical Services 
Team members D. Bernhard, D. Drown, E. Heydorn, and E. Schaub were knowledgeable of the hazards review method utilized, and possessed a general knowledge and understanding of the system under review. Team members E.

Schaub, V. Stein, and E. Heydorn has specific detailed knowledge of, and experience with, the system under review.

\section{PROCESS DESCRIPTION}

Refer to the Process Description in the Estimating Scope Report document.

\section{NOTES FROM PrHR MEETING}

1. D. Bernhard reviewed APCI's safety program and compared it to Eastman Chemical's. APCI's hazard criteria and safety design practices are acceptable to Eastman. APCI's hazard criteria for in-plant personnel is a fatal accident frequency rate (FAFR) of 0.4 fatalities per 100,000 exposure hours, for the total site, as well as for any isolatable individual plant. Specific risks to third parties are assessable quantitatively and reviewed and evaluated by senior management.

2. D. Bernhard reviewed APCI's Safety Plan for the LPMEOH project (Appendix 2). The following issues need to be addressed:

a. Eastman's list of OSHA PSM documentation requirements has more details and requirements than does APCI's. APCI will issue a listing of documents that we will produce for this project that are part of the OSHA PSM documentation (D. Drown). Eastman will review this list to determine if they or APCI should develop the added EMN requirements (L. Daniels).

b. APCI and EMN have developed internal safety standards and guidelines for designing, building, and operating industrial chemical plants. We will use APCI design standards for the LPMEOH project and some of Eastman's as requested. Eastman needs to inform APCI of any safety standard or practice which needs to be used or considered in the design of the LPMEOH plant (L. Daniels). Eastman will be issuing their P\&ID Design Handbook to APCI that has a section on Guidelines for Emergency Shutdown Systems (ESD). The guideline describes instrument and electrical design of shutdown systems to prevent hazardous releases, catastrophic failures, losses in property and life, and losses of production in chemical processes. This guideline requires a separate ESD for a class 1 and class 2 events. These events are described in the EMN guideline. APCI needs to include these requirements in the design of our shutdown systems.

c. The management of change was discussed. We need to agree on a way to document and manage change during and after plant start-up (E. Heydorn). 
3. D. Bernhard discussed what he will write up for the Site Risk Assessment that was done with Eastman at Kingsport on 26 January. The following issues need to be addressed during design of this project:

a. Location of discharge point of safety relief valves and impact on existing operations and the near-by house.

b. Congested plant site; consider in fire protection system design and materials handling during construction.

4. E. Schaub lead a discussion of the LPMEOH process.

a. EMN has nuclear (radiation) devices on-site and someone registered to handle them.

b. Consider need for cooler on stream from 29E-20 to the Lurgi Distillation area (Process).

c. Fuel grade methanol for the offsite fuel demonstrations will come form column $29 \mathrm{C}-10$ underflow and go to $29 \mathrm{D}-10$ or $29 \mathrm{D}-11$.

d. Process to consider raising the liquid knock-out vessels on the discharge of the reactor, so that pumps are avoided for flowing liquids back to the reactor (Process).

e. R. Moore to look at cost of higher pressure rating on column 29C-20.

f. The 600 psig steam tie-in to the boiler feed water for start-up should be shown on the PFD's (Process).

g. Reduction of catalyst will occur approximately once every 10 days.

Reduction is at $120 \mathrm{psig}$ and $240^{\circ} \mathrm{C}$. It takes $30-36$ hours for reduction. The initial charge of catalyst into the reactor is approximately 10 batches from the slurry prep tank. Alternatives to a nuclear density gauge (ndg) for the slurry prep tank should be considered (Process \& G. Marhefka).

h. The economics of oil recovery from the spent catalyst should be studied (R. Moore).

5. New equipment and technology items were discussed.

a. Reactor scale up from 13 TPD to 260 TPD was discussed.

b. The scale up of the 29E-02 reactor feed/product economizer is an issue. Experience with the type of design proposed will be tried at LaPorte AFDU in March.

c. APCI has experience with slurry pumps at the LaPorte AFDU. The Kingsport plant pumps will be sized for larger flow rates. 
d. Catalyst poisons in the syngas to the LPMEOH plant need to be identified (Process and Analytical).

e. Spent catalyst centrifuge recovery efficiency needs to be proven.

6. The chemicals to be used or made in the LPMEOH plant were discussed.

a. Physical Properties of Concern

Materials

i. Chemicals Made in Process

Methanol

Higher Alcohols

Dimethyl Ether

ii. Chemicals Used in Process
Hydrogen
Carbon Monoxide
Drakeol

iii. Catalysts \& Utilities

Catalyst

Nitrogen

Cooling Water

Steam

Boiler Feed Water

Heat Transfer Fluid

\section{Property of Concem}

Flammability

Flammability

Flammability

Flammability

Toxicity

Operate above flash point

Pyrophoric if dried out, nuisance dust

Asphyxiant

---

Thermal Burns

Thermal Burns

May be above its flash point

iv. Trace quantities in feed gas streams of Carbonyls, $\mathrm{H}_{2} \mathrm{~S}$ \& HS Toxicity

b. Eastman stated they experienced a corrosion problem with one of their methanol storage tanks. Carolina Eastman had inner granular stress corrosion cracking with wet recycle methanol. The methanol had $0.1 \& 0.2 \%$ formic acid and _ $\%$ water.

c. Project engineering will obtain MSDS for materials used and made in the LPMEOH plant (F. Frenduto).

d. The reactions were discussed.

$$
\begin{aligned}
& 2 \mathrm{H}_{2}+\mathrm{CO}=\mathrm{CH}_{3} \mathrm{OH} \\
& \mathrm{H}_{2}+\mathrm{CO}_{2}=\mathrm{CO}+\mathrm{H}_{2} \mathrm{O} \\
& 2 \mathrm{CH}_{3} \mathrm{OH}=\mathrm{CH}_{3} \mathrm{OCH}_{3}+\mathrm{H}_{2} \mathrm{O} \text { (trace amounts) }
\end{aligned}
$$

The DME reaction is limited by the amount of dehydration activity of the catalyst. 


\section{KINGSPORT LIQUID PHASE METHANOL PROJECT}

$00-3-8215$

Kingsport, Tennessee

VII. IDENTIFICATION OF HAZARDS

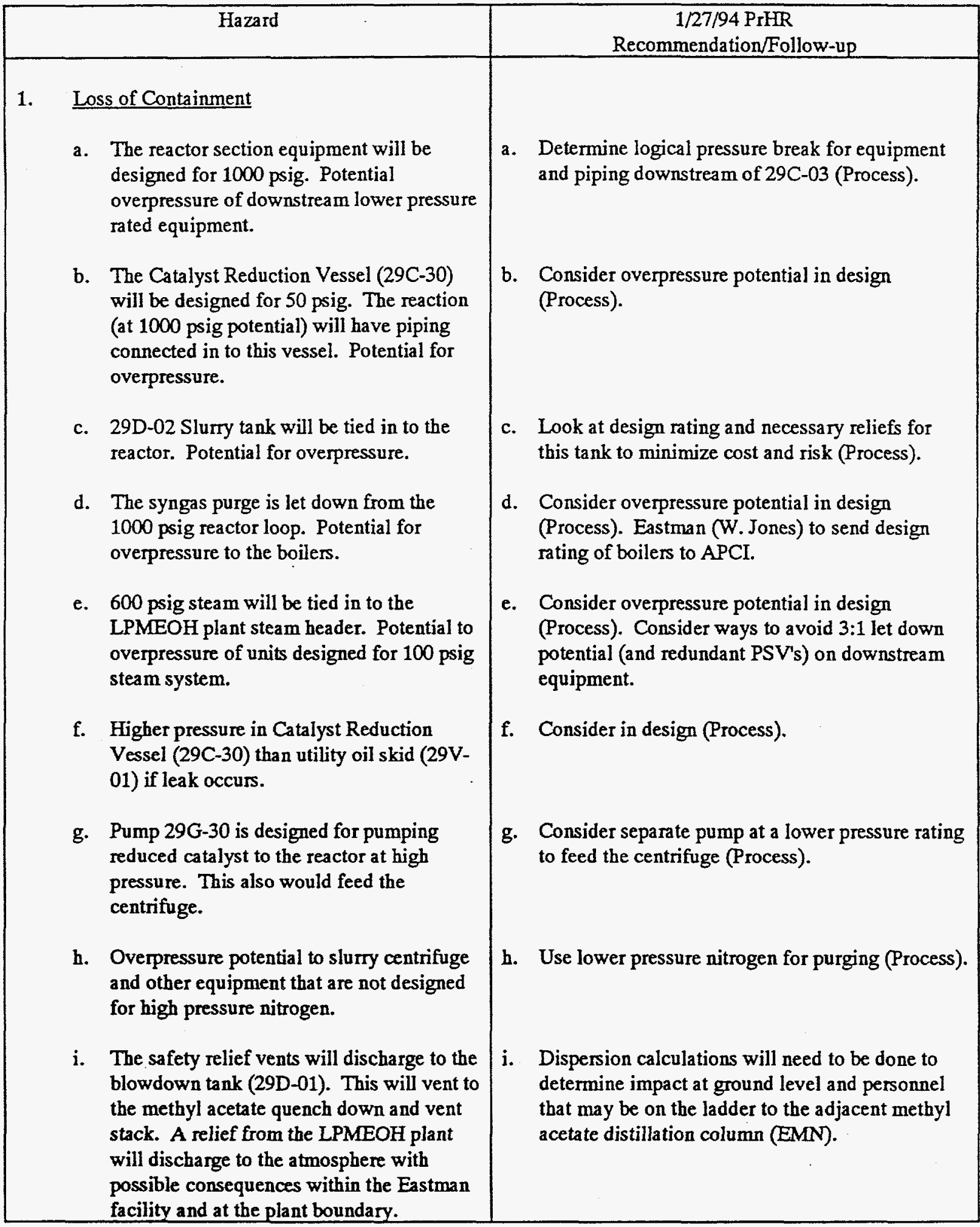




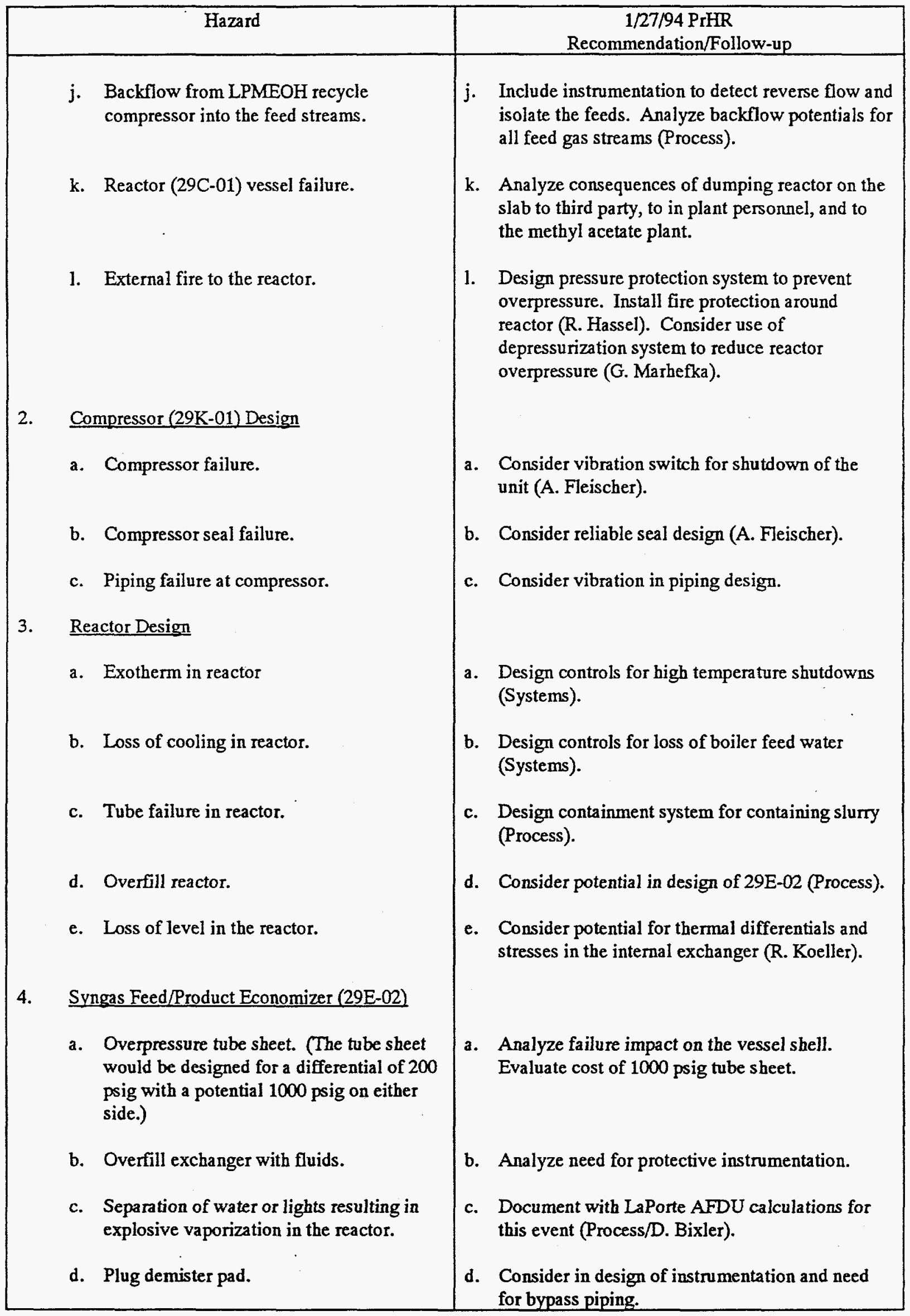




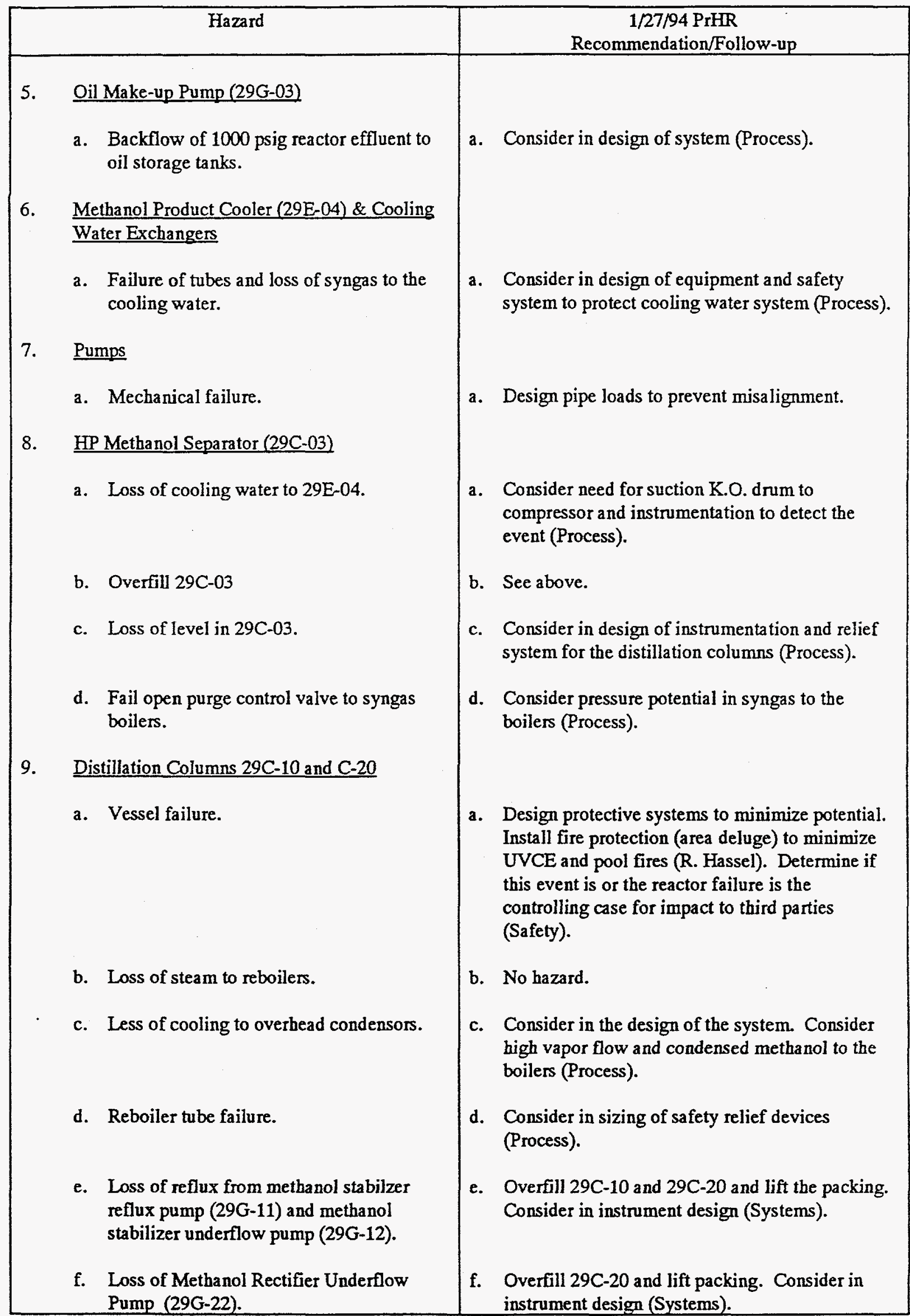




\begin{tabular}{|c|c|c|}
\hline & Hazard & $\begin{array}{c}\text { 1/27/94 PrHR } \\
\text { Recommendation/Follow-up }\end{array}$ \\
\hline & $\begin{array}{l}\text { g. Condensor tube failure. Pressure levels } \\
\text { unknown. Could get methanol in the } \\
\text { cooling tower or cooling water in the } \\
\text { distillation columns. }\end{array}$ & g. Consider in design (Process). \\
\hline & $\begin{array}{l}\text { h. Loss of level in methanol rectifier column } \\
\text { reflux drum (29CC-21). Demand on safety } \\
\text { protective systems. }\end{array}$ & h. Consider vapor load to storage tanks (Process). \\
\hline 10. & Lot Storage Tanks (29D-10 and D-11) & . \\
\hline & a. Overfill tanks. & $\begin{array}{l}\text { a. Overfill tanks and spill on the ground. Ground } \\
\text { will slope to drain to interceptor sewer that goes } \\
\text { to waste treatment plant. Include high level } \\
\text { alarm on tanks and fire protection (Systems). }\end{array}$ \\
\hline & b. Loss of nitrogen to storage tanks. & $\begin{array}{l}\text { b. Possible tank failure if vacuum is pulled when } \\
\text { pumping our of tank. Consider in design of tank } \\
\text { safeties (Process). }\end{array}$ \\
\hline & $\begin{array}{l}\text { c. Backpressure from plant } 31 \text { scrubber to } \\
\text { tanks. }\end{array}$ & c. Consider in system design (Process). \\
\hline
\end{tabular}




\section{APPENDIX 1}

KINGSPORT LPMEOH PROJECT

PRELIMINARY HAZARDS REVIEW

$1 / 27 / 94$

A GENDA

\section{Topic}

1. Introductions

2. Review Project Schedule and Current Status

3. Review of APCI and ECC Safety Program and Hazard Criteria

4. Review LPMEOH Project Safety Plan

5. Impact of OSHA PSM Regulations on This Project

6. Discuss Format for This Report

Process Discussion

7a. Review Project Scope of Work, Process

Description and PFD's

7b. Identify New Equipment or Technology Items

7c. Chemicals to be Used or Made in the Process (discuss properties, reactivity, stability, etc.)

8. Feed Gas Compressor Design

9. Discuss Relevant APCI Experience with LPMEOH at LaPorte

10. Identify Potential Major Hazards

11. Review Preliminary Plot Plan

12. Review Scope of Work for Eastman Chemical Company
Leader

All

D. Drown

D. Bernhard/

M. Templeton

D. Bernhard

D. Bernhard

All

E. Schaub
$5-10$

2 Hrs.

Expected

Time, Min.

5

5

$30-45$

$15-20$

$15-20$
A. Fleischer
$10-15$
E. Heydorn
$30-40$

All

3- 4 Hrs.

D. Drown $\quad 15-20$

D. Drown

$10-15$ 


\section{KINGSPORT LPMEOH PROJECT}

PRELIMINARY HAZARDS REVIEW

$1 / 27 / 94$

A GENDA

\section{Topic}

13. Discuss Fire Protection, Safe Distances, Drainage and Diking, Accessibility, Electrical Classification, Waste Collection/Disposal, and Third Party Considerations

14. Discuss Consequence to Other ECC Plants on Pipe or Vessel Failure

15. Review Philosophy of Control System as it Relates to Safety

16. Discuss Method for Conducting Design Hazards Review $\underline{\text { Leader }}$

All

All

All

All
$20-30$

$15-20$

30
Expected Time, Min.

$40-50$ 
Distribution

D. P. Drown/D. P. Bernhard

ate: . $\quad 17$ January 1994

bject: Kingsport Liquid Phase Methanol Project Safety Plan
Distribution

\section{$\underline{\mathrm{APCI}}$}

A. D. Bixler

W. R. Brown

T. E. Conway/M. K. Wolk

M. T. DiMercurio

S. L. Feldman

T. K. Hersh

E. C. Heydom

R. B. Moore

E.S. Schaub

G. E. Schmauch

V. E. Stein

J. Unangst
Dept./Loc::

Dept./Ext.: $\quad$ Proj. Eng./PSG Eng. Safety 


\section{EINGSPORT IIQUID PHASE METHANOL PROJECT}

\section{SAFETY PLAN}

APCI will design and build a 250 T/D Liquid Phase Methanol (LPMEOH) plant at Eastman Chemical Company's (ECC) Kingsport, TN plant. ECC will operate the plant during the demonstration period. The Safety Plan for this project includes a discussion on the requirement for producing the OSHA Process Safety Management documentation.

\section{Site Selection Risk Assessment}

A Site Selection Risk Assessment will be completed to identify safety and environmental risks to the project based on the site location for the LPMEOH. ECC will retain ownership of the land and the plant ownership will revert to ECC after the demonstration period. The location of the LPMEOH plant is an available area adjacent to part of their existing Methyl Acetate plant.

\section{Safety Reviews}

The IPMEOH plant involves new technology and hazardous materials and is therefore considered a High Risk Facility according to PSG Engineering Safety Work Instruction ES09011. The following safety reviews will be required. The groups with required attendance at these reviews are noted.

\section{Safetv Review}

Site Selection Risk Assessment

Preliminary Hazards Review (PrHR)

Flowset forit Reviexe

Plot Plan/Facility Arrangement Review

Design Hazards Review (DHR)

Design Verification Review (DVR)

\section{Required Attendance By}

Project, Safety

Safety, ECC, Process, Project, Engineering Technology, Systems, Operations (LaPorte AFDU)

Safety, ECC, Process, Systems: Machinery (for machinery items)

Safety, ECC, Process, Project: Design Coorcinator for PSG Engineering

Safety, ECC, Process, Project, Engineering Technology, Sysiems, Operations (Part-Time)

Safety, Process, Project, Systems, ECC 


\title{
KINGSPORT LIQUID PHASE METHANOL PROJECT
}

\author{
SAFETY PLAN
}

Safetv Review

Operation Readiness Inspection (ORI)
Required Attendance By

Safety, ECC, Process, Project, Construction, Systems, Operations (LaPorte AFDU)

Project Engineering will initiate and coordinate the setting of these safety reviews.

A "Hazop" or "Hazop/That If" combination analysis will be used to analyze hazards in the DHR.

\section{Fire Protection System}

The existing firewater system will be extended for the new LPMIEOH plant. The scope of the additions will be reviewed as part of the DHR.

\section{Vent System Review}

Process Engineering will define the release rates and composition of vents. PSG Engineering Safety will assist defining any design features and procedures neecied to insure safe operation.

\section{Electrical Area Classification Plan}

The Electrical Area Classification Plan will be reviewed by PSG Engineering Safety, Fiucess, Operations, ECC, Project and PSG Electrical Engineering.

\section{OSHA Process Safety Management Compliance}

Since this plant will be above the threshold for flammable material (10,000 lbs.), the plant owner is required as part of OSHA promulgated regulation for Process Safety Management (PSiv) to provide the information to document the safety of the facility operations. APCI and ECC will agree on the scope of information to be proviced by APCI to ECC for this project. A list of the "typical" PSM deliverables is atiached. The responsibility column will need to be modinied for this project.

A Preliminary Hazarcis Review will be performed with the PFD and the piot plan as the basis for the review. 


\section{EINGSPORT LIQUID PHASE METHANOL PROJECT}

\section{SAFETY PLAN}

7. Eastman Chemical Company Safety Standards

APCI and ECC will agree on a set of safety standards to apply to the design and construction of this plant. The construction contractors will have to comply with the contractor requirements of the OSHA PSM regulations unless adequate segregation of the construction area from the existing ECC plants can be achieved.

8. Changes to the Safety Plan

The APCI Project Engineer will document and communicate to the appropriate personnel any safety review plan changes that occur during project execution. 

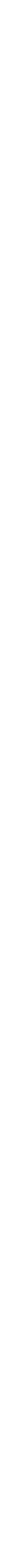

APPENDIX 3 


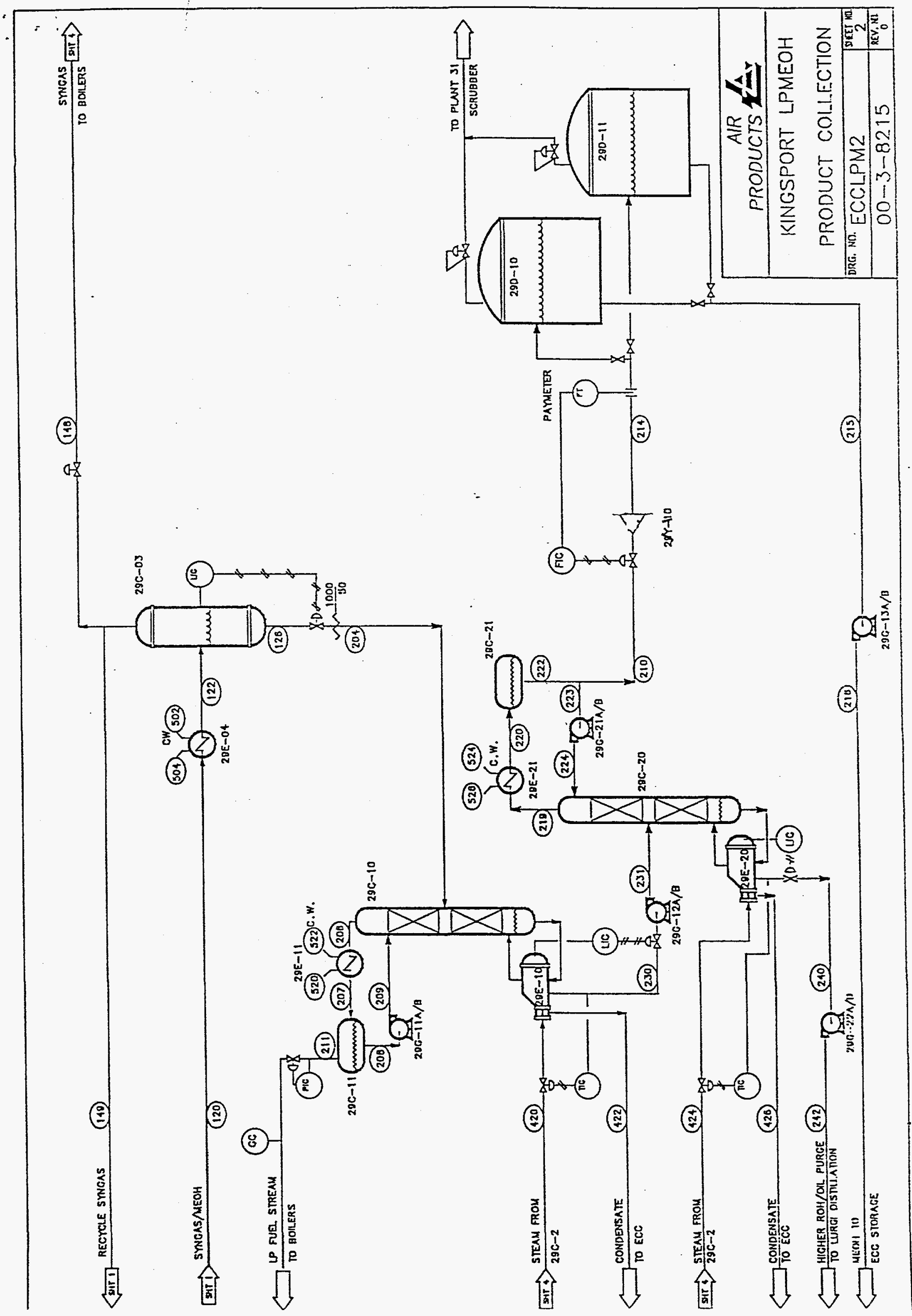




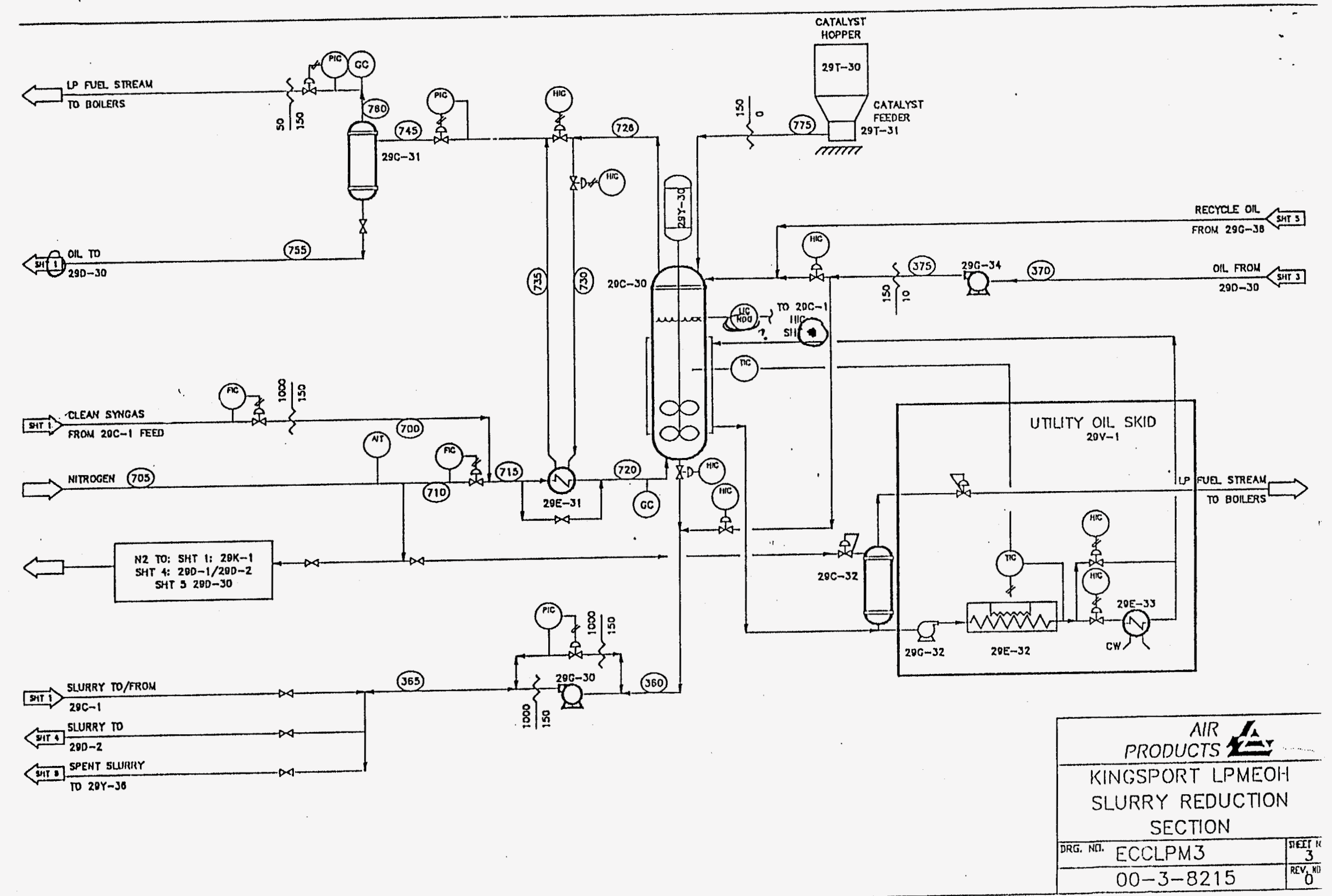




\section{APPENDIX C MILESTONE SCHEDULE 6/24/94 1Page}




\section{MILESTONE SCHEDULE STATUS REPORT LIQUID PHASE METHANOL DEMONSTRATION DE-FC22-92PC90543}

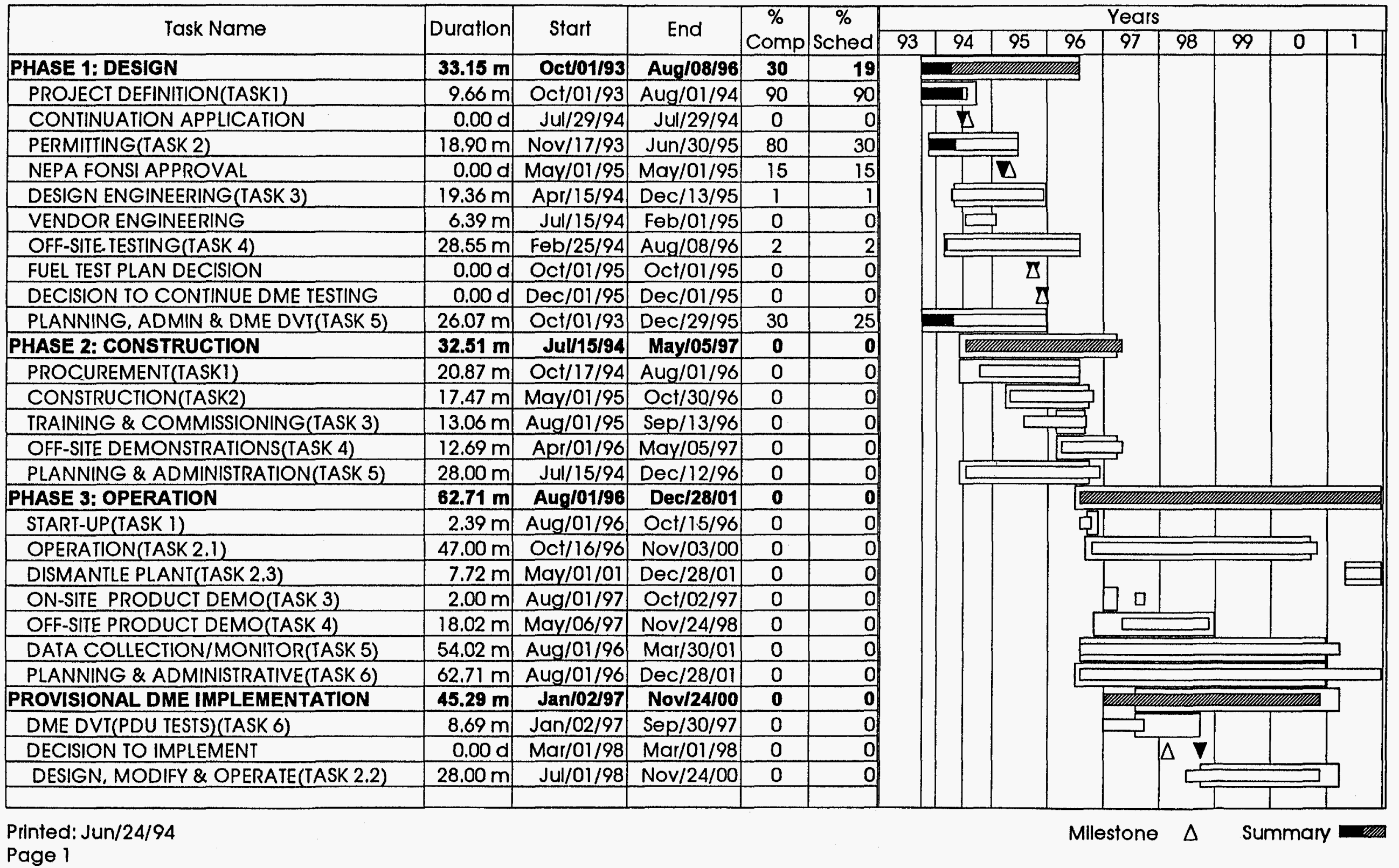


APPENDIX D COST MANAGEMENT REPORT 6/94 1Page 


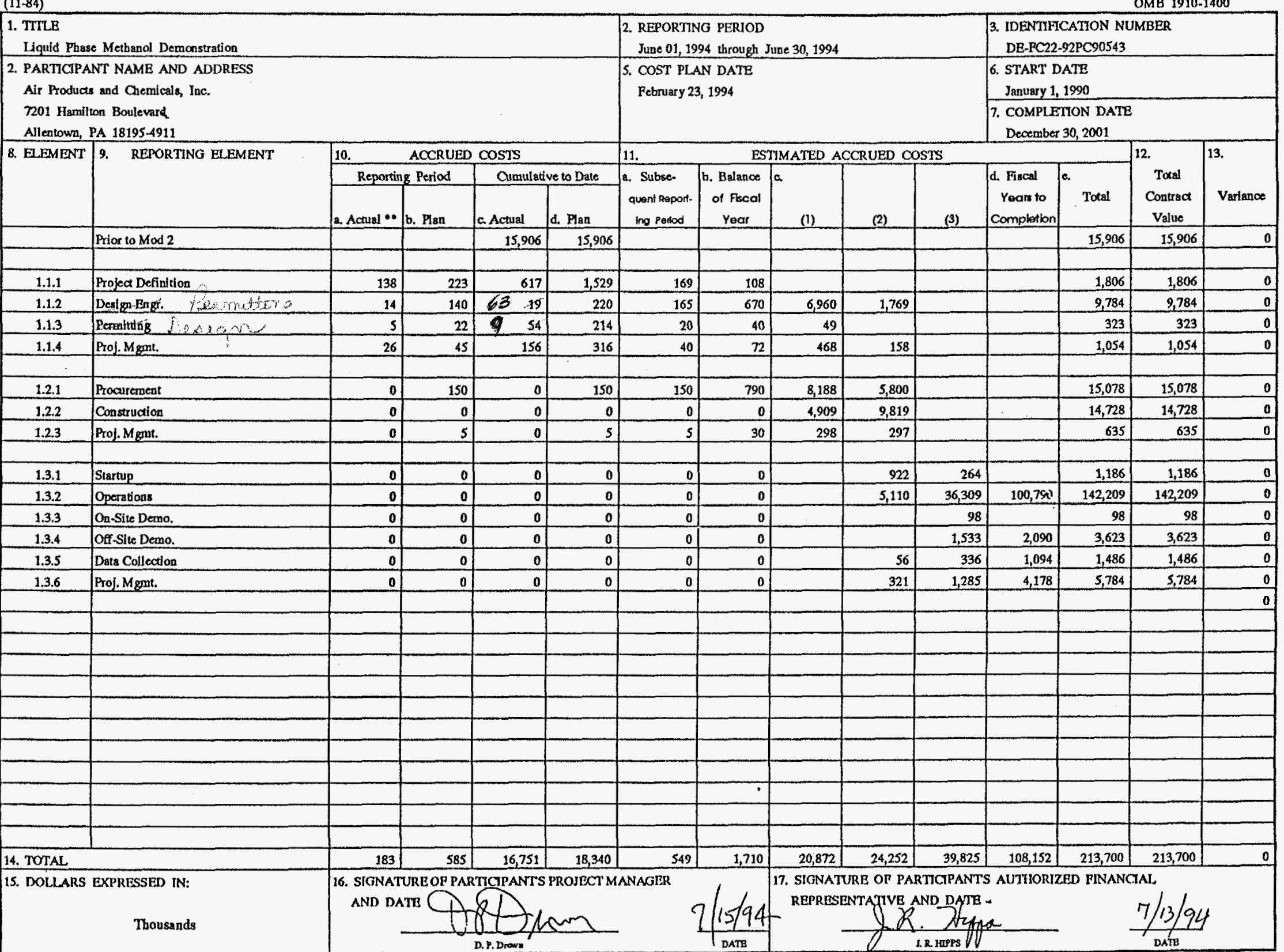

** NOTE: Excludes spending by Eastman Chemical and Acurex not yet involced. 